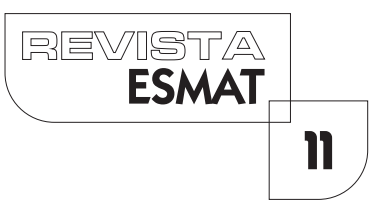

\title{
UM DEBATE SOBRE A DESCRIMINALIZAÇÃO DA MACONHA SOB O ENFOQUE DA CRIMINOLOGIA CRÍTICA E A AUDIÊNCIA DE CUSTÓDIA COMO FERRAMENTA CONTRA A PRISÃO CAUTELAR
}

A DEBATE ON MARIJUANA DESCRIMINALIZATION OVER A CRITICAL CRIMINOLOGY PERSPECTIVE AND THE ROLE PLAYED BY CUSTODY HEARING AS A TOOL AGAINST PROVISIONAL PRISONING

Yuri Anderson Pereira Jurubeba

Mestrando no Programa de Mestrado Profissional Interdisciplinar em Prestação Jurisdicional e Direitos Humanos da Universidade Federal Tocantins (UFT) em colaboração com a Escola Superior da Magistratura do Estado do Tocantins (ESMAT).E-mail:yuri.jurubeba@yahoo.com.br

Tarsis Barreto Oliveira

Professor no Programa de Mestrado Profissional e Interdisciplinar em Prestação Jurisdicional e Direitos Humanos da UFT em colaboração com a Escola Superior da Magistratura do Estado do Tocantins (ESMAT). E-mail: tarsisbarreto@uft.edu.br

Luiz Antônio Francisco Pinto

Mestrando no Mestrado Profissional Interdisciplinar em Prestação Jurisdicional e Direitos Humanos da UFT em colaboração com a Escola Superior da Magistratura do Estado do Tocantins (ESMAT).E-mail:judconluiz@yahoo.com.br

Paulo Sérgio Gomes Soares

Professor no Programa de Mestrado Profissional e Interdisciplinar em Prestação Jurisdicional e Direitos Humanos da UFT em colaboração com Escola Superior da Magistratura do Estado do Tocantins (ESMAT).E-mail: psoares@uft.edu.br

\section{RESUMO}

O objetivo deste artigo é expor um debate contextualizado sobre a descriminalização da maconha para uso próprio, sob o enfoque metodológico da Criminologia da Crítica (CARVALHO, 20I3), pela consolidação das políticas criminais alternativas. Considerase no debate a repercussão geral do Recurso Extraordinário n 635.659/SP, que tramita no STF. Para além de uma análise jurídica, o tema abordado figura num contexto social com muitas contradições e diferentes aspectos que precarizam a vida e vulnerabilizam a juventude. Os dados divulgados pelo Infopen (20l4) mostram que o sistema penal brasileiro e tocantinense é seletivo e recai sobre pobres, negros e desempregados com baixo nível escolar. Para evitar danos sociais maiores às pessoas, a Audiência de Custódia 
pode ser importante ferramenta contra a prisão cautelar. $O$ problema que procuramos elucidar é que a criminalização do uso e porte da maconha se soma à expansão de outros tipos penais, mais graves e com alta periculosidade, contribuindo para o encarceramento massivo de pessoas num sistema penitenciário superlotado e em condições que desrespeitam os Direitos Humanos.

PALAVRAS-CHAVE: Descriminalização da maconha; Criminologia crítica; Direitos humanos; Recurso Extraordinário n 635.659/SP; Audiência de custódia.

\section{ABSTRACT}

The aim of this article is to present a contextualized debate over marijuana descriminalization on behalf of drug users, under a methodological perspective of critical criminology (CARVALHO, 20I3) on the consolidation of alternative criminal policies. We consider in this debate the general juridical effects of the Extraordinary Appealing $n$. 635.659/SP, in STF. Far beyond a juridical analysis, the object of this study considers a social context with lots of contradictions and different aspects that weeken life and turns youthness vulnerable. The divulged data from Infopen (2014) show that Tocantins and brazilian penal systems are selective and cause effetcs over the poor, black and unemployed people with low scholarly level. In order to avoid bigger social damages to people, Custody Hearing can turn to be an important alternative against provisional prisoning. The problem we try to elucidate is that the criminalization of drug users and marijuana carrying are additioned to the expansion of other crimes, even more serious ones, and with higher perilously, turning to cause massive people prisoning in a crowded penitentiary system with no respect of Human Rights conditions.

KEYWORDS: Marijuana descriminalization; Critical criminology; Human rights; Extraordinary Appealing n 635.659/SP; Custody hearing.

\section{INTRODUÇÃO}

No Brasil, atualmente, a hegemonia do positivismo jurídico tem sido questionada como única forma de resolver os problemas sociais. Não é mais possível a concepção antiquada do positivismo criminológico pautada na violência estatal das agências penais, cujo combate à criminalidade incide sobre as pessoas já estigmatizadas enquanto classe social, produzindo danos sociais maiores do que os delitos praticados.

Está em curso o paradigma da reação social que interfere diretamente nas políticas criminais a partir de bases macrossociológicas e macrocriminológicas para a compreensão do fenômeno da criminalidade, opondo-se ao paradigma liberal- 
UM DEBATE SOBRE A DESCRIMINALIZAÇÃO DA MACONHA SOB O ENFOQUE DA CRIMINOLOGIA CRÍTICA E A AUDIÊNCIA DE CUSTÓDIA COMO FERRAMENTA CONTRA A PRISÃO CAUTELAR

individualista, que é microcriminológico e despolitizado. Não é mais possível olhar para o indivíduo de forma isolada, mas como produto social, cujo processo de inserção no mundo da criminalidade possui múltiplas determinações.

Na primeira seção, os dados trazidos pelo Infopen (20l4) mostram que a estrutura do sistema penitenciário se ancora na segregação social, isto é, num modelo específico de política criminal ideológica que atende aos interesses dominantes. Num país cuja pobreza da maioria da população é evidente devido à péssima distribuição de renda e fundiária, a tendência do consenso social para evitar a marginalidade é cristalizar um sistema de seleção e tipos penais que representam perigo para a manutenção do poder. Os dados mostram as características da maioria dos presos - pobres, negros e com baixo nível educacional -, que não são diferentes das características de boa parte da população brasileira. Nesse sentido, a seletividade dos tipos penais aprofunda o fosso entre as classes sociais e agrava os problemas sociais.

Metodologicamente, este artigo analisa o problema da descriminalização da maconha a partir da Criminologia Crítica, apontando dados empíricos publicados pelo Infopen sobre a população carcerária e os problemas do sistema penal brasileiro e, também, do Estado do Tocantins. O que se pretende evidenciar são as contradições. A criminalização do uso e porte da maconha se soma à expansão de outros tipos penais, mais graves e com alta periculosidade, contribuindo para o encarceramento massivo de pessoas num sistema penitenciário superlotado e em condições que desrespeitam os Direitos Humanos.

A segunda seção analisa o debate acerca da repercussão geral do Recurso Extraordinário $n^{\circ}$ 635.659/SP, que tramita no STF, sobre a descriminalização da maconha que, a despeito do preconceito e pouco debate público, ganhou destaque pela defesa incontestável dos ministros Gilmar Mendes, Luís Roberto Barroso e Edson Facchim, em prol da descriminalização para uso próprio, considerando a inconstitucionalidade do acautelamento dos usuários, devido aos problemas sociais decorrentes dos danos sociais provocados pelo próprio sistema penal.

A terceira seção traz um debate macrossociológico que evidencia alguns critérios sociais para avaliar a moralidade na ação de um sujeito, os quais precisam estar intimamente relacionados com as práticas sociais em que este está envolvido, considerando até mesmo a cultura que permeia a vida dele e as múltiplas determinações históricas. Os valores possuem fundamento cultural e, muitas vezes, material, que não podem ser desconsiderados pela criminologia. $\bigcirc$ problema é que em questões que demandam avaliação jurídica, prevalece a abstração do que é justo e racional, a despeito dos problemas sociais causados pela cultura do consumo e desemprego (sobretudo entre os jovens) decorrentes da crise do capitalismo.

A última seção evidencia que enquanto não ocorrer o processo de descriminalização da maconha, visto como tipo penal de menor potencial ofensivo, a Audiência de Custódia pode ser importante ferramenta para a redução da prisão cautelar. 


\section{A SITUAÇÃO DOS PRESÍDIOS BRASILEIROS E DO ESTADO DO TOCANTINS}

Hoje, em todo o Brasil, há 1,6 presos por vaga nos presídios. O relatório do Sistema Integrado de Informações Penitenciárias (INFOPEN), disponibilizado pelo Ministério da Justiça no dia 23 de junho de 2014, aponta que a população carcerária cresceu 16 | \% nos últimos I 5 anos, alcançando o número de 607.73 I presos no Brasil. Contudo, o país possui apenas 375.892 vagas.

O problema é que, conforme o relatório do Infopen, 4 em cada 10 acautelados são presos provisórios, ou seja, 4l\% das pessoas privadas de liberdade encontram-se encarceradas sem terem sido condenadas por sentença definitiva.

Nesse cenário, destaca-se, ainda, que o número de pessoas presas deve aumentar consideravelmente nos próximos anos, considerando-se a crise econômica, o desemprego (sobretudo entre os jovens) e a precarização da vida das pessoas, fatores que ocasionam o crescimento dos diferentes tipos penais, sem que haja o devido acompanhamento no crescimento do número de vagas nos presídios.

Em 17 de fevereiro de 2016, ao julgar o habeas corpus n 126.292,' o Supremo Tribunal Federal (STF) alterou o entendimento consolidado na jurisprudência, passando a permitir a execução da pena criminal com a confirmação em segundo grau das condenações. ${ }^{2}$ Diante disso, ainda que exista recurso pendente de decisão, se em sede de $2^{\circ}$ grau houver a confirmação da decisão condenatória proferida por magistrado singular, é possível a prisão do acusado para o cumprimento de sua pena.

Sem adentrar em seu mérito, o que se percebe é que o novo posicionamento da Suprema Corte ensejará a antecipação do encarceramento das pessoas condenadas pela prática de crimes, o que deverá impactar diretamente no quantitativo de presos do nosso sistema carcerário.

Na ocasião do julgamento, o presidente da Corte, Ricardo Lewandowski, expôs sua "perplexidade com esta guinada da corte", uma vez que, "em duas oportunidades (ADPF 347 e no Recurso Extraordinário n592.58 I), o Supremo reconheceu que o sistema carcerário brasileiro 'está absolutamente falido". Acrescentou, ainda, o presidente do STF: "E agora vamos facilitar a entrada das pessoas neste verdadeiro Inferno de Dante, abrandando esse princípio maior da nossa Carta Magna? Isso me causa a maior estranheza". ${ }^{3}$

' Disponível em: http://www.migalhas.com.br/arquivos/20 I 6/2/art201602 17-10.pdf Acessado em I2/5/2016.

${ }^{2}$ CANÁRIO, Pedro. STF muda entendimento e passa a permitir prisão depois de decisão de segundo grau. Disponível em: http://www.conjur.com.br/20/6-fev-17/supremo-passapermitir-prisao-depois-decisao-segundo-grau Acessado em 12/5/2016.

${ }^{3}$ LEWANDOWSKI, Ricardo. In: CANÁRIO, Pedro. STF muda entendimento e passa a permitir prisão depois de decisão de segundo grau. Disponível em: http://www.conjur.com.br/20 I 6-fev17/supremo-passa-permitir-prisao-depois-decisao-segundo-grau Acessado em 12/5/20 16. 
UM DEBATE SOBRE A DESCRIMINALIZAÇÃO DA MACONHA SOB O ENFOQUE DA CRIMINOLOGIA CRÍTICA E A AUDIÊNCIA DE CUSTÓDIA COMO FERRAMENTA CONTRA A PRISÃO CAUTELAR

Vale ressaltar que há presídios em que o quadro de superlotação retrata o ócio, a violência, a corrupção e a propagação de doenças infectocontagiosas (VASCONCELOS, 20 I0). Certamente, o aumento do contingente carcerário irá piorar muito as condições.

Dentro dos presídios se formam as chamadas "escolas do crime". Lá, um tipo penal "corrigível", isto é, que poderia passar por tratamento ou qualquer processo de ressocialização, efetivamente, pode perder essa chance e se tornar um verdadeiro problema social. Portanto, as prisões precisam ser encaradas como a última fronteira, quando não há mais possibilidade, isto é, quando o indivíduo foi devidamente julgado e condenado por um crime, devendo cumprir a sentença, conforme estipula a lei, em estabelecimentos que garantam a dignidade da pessoa humana, como preveem os Direitos Humanos.

Goffman (apud RIBEIRO, 2008, pp. I20- I 2I) faz considerações importantes sobre as consequências sofridas pelo indivíduo ao cumprir pena:

Ao ingressar nesse sistema social extremamente complexo, o interno é submetido a uma série de 'rebaixamentos, degradações, humilhações e profanações do eu', passando por um processo de modificações radicais nas concepções que tem a seu respeito e a respeito das pessoas que são significativas para si. [...] Realmente, o interno é despojado do papel que anteriormente ocupava na sociedade e é codificado como um objeto, ingressando mecanicamente na máquina administrativa do estabelecimento, através de operações de rotina.

Ainda sobre as consequências, enfatiza Thompsom (1995, p. 73):

A uma pessoa no mundo livre, que conhece a penitenciária apenas através de relatos, ou de visitas esporádicas, fica difícil avaliar o grau de sofrimento a que os presos estão submetidos em função da impossibilidade de se defender, eficazmente, das agressões, ataques e abusos de toda a ordem, que são lugarcomum no meio carcerário.

No Brasil, é sabido que os presídios não respeitam os Direitos Humanos. Os presos adultos são amontoados em condições insalubres, sem higiene e estrutura adequada ao processo de ressocialização, isto é, sem acesso a qualquer política universal para reduzir a reincidência ou, ao menos, para garantir os direitos fundamentais da pessoa humana. Há de se considerar, ainda, que a reinserção social é dificultada por diferentes problemas, como o preconceito e a exclusão, gerando um processo insolúvel de problemas sociais.

Sendo assim, três críticas são potencializadoras para que se reflita sobre estratégias que possam reduzir o contingente carcerário e os danos sociais aos acautelados, produzidos pelo sistema penitenciário: I . O sistema penal não cumpre as funções que 
Ihe foram atribuídas, isto é, não diminui a criminalidade, não ressocializa e consome cifras expressivas de dinheiro público para a sua manutenção; 2. Produz um custo social muito alto, se for considerado o fato de que a pessoa criminalizada ganha do sistema penal um rótulo, um estigma, cujos efeitos são extremamente negativos para a reinserção social; 3. Em muitos e diferentes aspectos fere os Direitos Humanos.

Em junho de 2015, o Plenário do Supremo Tribunal Federal recebeu do Partido Socialismo e Liberdade um pedido de reconhecimento das violações dos direitos fundamentais dos presos e iniciou o julgamento da cautelar na Arguição de Descumprimento de Preceito Fundamental $n^{\circ} 347 .{ }^{4}$ Conforme a reportagem de Rômulo de Andrade Moreira, ${ }^{5}$ o ministro Marco Aurélio Mello observou

que a maior parte dos detentos está sujeita a condições como superlotação, torturas, homicídios, violência sexual, celas imundas e insalubres, proliferação de doenças infectocontagiosas, comida imprestável, falta de água potável, de produtos higiênicos básicos, de acesso à assistência judiciária, à educação, à saúde e ao trabalho, bem como amplo domínio dos cárceres por organizações criminosas, insuficiência do controle quanto ao cumprimento das penas, discriminação social, racial, de gênero e de orientação sexual. Diante disso, segundo o relator, no sistema prisional brasileiro ocorre violação generalizada de direitos fundamentais dos presos no tocante à dignidade. 'O quadro é geral, devendo ser reconhecida a inequívoca falência do sistema', afirmou.

ministro chegou a falar sobre o direito de indenização dos presos por danos morais, conforme Ação Direta de Inconstitucionalidade (ADI) n 5. I70, bem como de obrigar os Estados e a União a fazer obras nos presídios, pelo uso do Recurso Extraordinário n ${ }^{\circ} 592.581$; outro ponto apontado pelo ministro, que requer obrigação, é bloquear os sinais de rádio e de celular nos presídios (ADI n 5.356).

Certamente os pontos apontados pelo ministro evidenciam que os presídios apenas pioram as condições morais dos presos, além de permitir brechas que facilitam a integração das organizações criminosas. Acaso é esse o destino que queremos para os jovens brasileiros, sobretudo esses presos provisoriamente por porte de maconha para uso próprio? Considera-se inaceitável essa realidade. Principalmente se for levada em consideração a questão da redução da maioridade penal, que irá colocar o adolescente infrator, preso usando ou portando maconha, num sistema carcerário incapaz de reinseri-lo como adulto no seio social.

\footnotetext{
${ }^{4}$ MOREIRA, Rômulo A. Uma vitória pírrica: o julgamento da ADPF 347. Disponível em: http://romulomoreira.jusbrasil.com.br/artigos/232387594/uma-vitoria-pirrica-o-julgamentoda-adpf-347 Acessado em 12/5/2016.

${ }^{5}$ Disponível em: http://romulomoreira.jusbrasil.com.br/artigos/232387594/uma-vitoria-pirricao-julgamento-da-adpf-347 Acessado em 12/5/2016.
} 
UM DEBATE SOBRE A DESCRIMINALIZAÇÃO DA MACONHA SOB O ENFOQUE DA CRIMINOLOGIA CRÍTICA E A AUDIÊNCIA DE CUSTÓDIA COMO FERRAMENTA CONTRA A PRISÃO CAUTELAR

ministro Barroso destacou três prioridades ao descriminalizar a maconha para consumo próprio, dentre elas a seguinte:

deve-se impedir que as cadeias fiquem entupidas de jovens pobres e primários, pequenos traficantes, que entram com baixa periculosidade e na prisão começam a cursar a escola do crime, unindo-se a quadrilhas e facções. Há um genocídio brasileiro de jovens pobres e negros, imersos na violência desse sistema. ${ }^{6}$

Ainda há de se destacar que, no Brasil, o direito penal é seletivo e com viés para punição de pessoas pobres, negras e em condições sociais desfavoráveis. Nessa perspectiva, conforme Argüero e Muraro (20 I 5, p. 33 I ), num Estado que não oferece condições sociais dignas aos cidadãos, há certa tendência minimalista nas políticas públicas e maximalistas nas políticas de intervenção repressiva para a manutenção da lei e da ordem.

De acordo com os dados do Infopen (20 I4, p. 48), "56\% da população prisional é composta por jovens, essa faixa etária compõe apenas $21,5 \%$ da população total do país", faixa etária entre 18 e 29 anos, de acordo com o Estatuto da Juventude.

Quanto ao perfil dos jovens encarcerados no sistema prisional brasileiro, considerando-se a raça, a cor e a etnia, ${ }^{7}$ é o seguinte: "dois em cada três presos são negros. Ao passo que a porcentagem de pessoas negras no sistema prisional é de 67\%, na população brasileira em geral, a proporção é significativamente menor (5l\%)" (INFOPEN, 20|4, p. 50).

Em grande medida, são "[...] réus com escolaridade primária e baixa renda (não contratam advogados, há um grande número de desempregados), com os negros sobre-representados e há o predomínio de réus jovens e de sexo masculino características que correspondem ao esteriótipo criminal" (BARRETO, 2006, p. 67).

O grau de escolaridade da população prisional brasileira é extremamente baixo. [...] aproximadamente oito em cada dez pessoas presas estudaram, no máximo,

\footnotetext{
${ }^{6}$ BARROSO, Luís Roberto. RE 635.659/SP. Descriminalização do porte de drogas para consumo próprio: anotações para o voto oral do Ministro Luís Roberto Barroso. Disponível em: http://s.conjur.com.br/dl/leia-anotacoes-ministro-barroso-voto.pdfAcessado em 12/5/20 6.

7 "Para os fins do presente relatório, entende-se raça como o grupo definido socialmente em razão de características físicas. Por etnia entende-se grupo definido pelo compartilhamento histórico, religioso ou cultural. A categoria negra inclui pretos e pardos." (INFOPEN, 20 I 4, p. 50). Disponível em: http://www.justica.gov.br/noticias/mj-divulgara-novo-relatorio-do-infopennesta-terca-feira/relatorio-depen-versao-web.pdfAcessado em 17/5/2016.
} 
até o ensino fundamental, enquanto a média nacional de pessoas que não frequentaram o ensino fundamental ou o têm incompleto é de $50 \%$. Ao passo que na população brasileira cerca de $32 \%$ da população completou ensino médio, apenas $8 \%$ da população prisional o concluiu. Entre as mulheres presas, esta proporção é um pouco maior ( I 4\%). (INFOPEN, 20 I 4, p. 58).

No estado do Tocantins, por sua vez, a condição dos presos apresenta a seguinte configuração em relação à educação (INFOPEN, 20|4): 7\% dos presos são analfabetos; 9\% são alfabetizados (sem cursos regulares); 44\% possuem o Ensino Fundamental Incompleto; I5\% possuem o Ensino Fundamental Completo; I4\% possuem Ensino Médio Incompleto; 9\% possuem o Ensino Médio Completo; I\% possui o Ensino Superior Incompleto; I \% possui o Ensino Superior Completo; e acima do Ensino Superior Completo o percentual 0\%.

O estado do Tocantins possui 43 unidades prisionais, com um total de 2.284 vagas, contando com a capacidade média de 53 vagas e com o máximo de 432 vagas numa unidade, cabendo ressaltar que há unidades com diferentes capacidades. Quanto ao déficit de vagas no sistema prisional, no Tocantins, a taxa de ocupação proporcional de pessoas presas por vaga é de 142\%, ou seja, os espaços feitos para custodiar 10 indivíduos têm, em média, mais de |4. Dos 2.795 presos no Estado, apenas 405 estão em estabelecimentos sem déficit de vagas; 1.537 estão em estabelecimentos com até duas pessoas por vaga; I.037 até três pessoas por vaga; e 17। mais de quatro pessoas por vaga (INFOPEN, 20I4). Esses dados permitem vislumbrar o quadro de superlotação.

Dos sentenciados, 495 estão em regime semiaberto; 748 em regime fechado (o déficit ou população excedente é de 586 vagas); provisórios 1.031 (o déficit ou população excedente é de 405 vagas). $\bigcirc$ estado do Tocantins apresenta um total de $58 \%$ de jovens encarcerados na faixa etária entre 18 e 29 anos, percentual maior do que a média nacional que é de $56 \%$.

Em relação à raça, cor e etnia, o Estado apresenta a seguinte configuração: I5,3\% são brancos e $82,3 \%$ são negros. Conforme já constatado, a população carcerária é, em sua maioria, jovem, negra e com baixo grau de escolaridade, e no estado do Tocantins a situação se mostra mais evidente.

Os dados trazidos pelo Infopen, a título de pesquisa empírica e por onde deve começar qualquer estudo sério que pretenda apontar alternativas ao sistema punitivo, mostram que a estrutura do sistema penitenciário se ancora na segregação social, isto é, num modelo específico de política criminal.

[...] estruturada nas ideias de consenso social, patologia do criminoso, objetividade das estatísticas e gravidade do delito comum, ascende ao enfoque macro proposto pela Criminologia Crítica, no qual a reação social e os processos de seleção, etiquetamento e estimatização demonstram nova forma da violência: a violência estatal das agências penais. (CARVALHO, 2013, 172-173). 
UM DEBATE SOBRE A DESCRIMINALIZAÇÃO DA MACONHA SOB O ENFOQUE DA CRIMINOLOGIA CRÍTICA E A AUDIÊNCIA DE CUSTÓDIA COMO FERRAMENTA CONTRA A PRISÃO CAUTELAR

A Criminologia Crítica sustenta, portanto, que esse modelo de política criminal e de sistema penal é mero instrumento de controle social e se organiza ideologicamente conforme os interesses dominantes. Ora, os dados do Infopen mostram exatamente as características da maioria dos presos - pobres, negros e com baixo nível educacional -, que caracterizam, também, boa parte da população brasileira.

Evidentemente, o sistema penal é seletivo e recai sobre essas pessoas já estigmatizadas enquanto classe social. Nesse sentido, a violência estatal representa a violência de classe e a manutenção do poder e da dominação. "[...] Percebeu-se que a reação contra o delito conduzida pelas agências oficiais de punitividade caracteriza-se pela seletividade e pela desigualdade, gerando danos muitas vezes superiores aos do próprio delito praticado (violência institucional)" (CARVALHO, 20I3, p. I69).

Evidentemente, há certa tensão na política criminal contemporânea em que se confrontam a criminalização e a descriminalização. No caso da descriminalização, a sua base argumentativa se apoia em políticas criminais alternativas que procuram fazer a gestão do ato delitivo, ou seja, evita a reação punitiva, típica da criminalização. De certa forma, a descriminalização se apresenta como alternativa para condutas delitivas com baixo potencial ofensivo, diminuindo, assim, o acautelamento que, como já salientado, não ressocializa, desrespeita os Direitos humanos e apresenta um alto custo social para as pessoas e econômico para o Estado.

Ora, enquanto os holandeses utilizam suas prisões ${ }^{8}$ e forma provisória para abrigar os refugiados e imigrantes nesses tempos sombrios de crise do humanismo no mundo, no Brasil, reclama-se da falta de presídios para encarcerar mais pessoas e jovens (vide o debate sobre o rebaixamento da idade de imputabilidade penal). No Brasil, a ideologia dominante foi introjetada e se enraizou na subjetividade das pessoas em geral. Os meios de comunicação de massa têm uma parcela de responsabilidade pela formação da opinião pública quando veiculam os programas sensacionalistas e jornais que mostram situações explícitas de violência, banalizando e naturalizando-as. Reforça-se nas pessoas a opinião de que a repressão e o encarceramento são as melhores alternativas, quando, na verdade, o país possui problemas sociais históricos de exclusão social, péssima distribuição fundiária e de renda, desigualdades de todos os tipos, qualidade na educação duvidosa, sistema de saúde precário etc.

\footnotetext{
${ }^{8}$ A criminalidade está diminuindo na Holanda, e o país procura novas maneiras de usar seus presídios. [...] Agora, com o fluxo enorme de refugiados e imigrantes que chegam à Europa, vários presídios holandeses estão sendo usados como abrigos temporários para candidatos a asilo no país." In: MUHEISEN, Muhammed (da Associated Press, em Haarlem, Holanda). Com criminalidade em queda, Holanda abriga refugiados em cadeias ociosas. Disponível em: http://wwwl folha.uol.com.br/mundo/20 I6/05/I 772722-com-criminalidade-em-quedaholanda-abriga-refugiados-em-cadeias-ociosas.shtml Acessado em: 25/6/20l6.
} 
Vivemos, hoje, sob a égide da concepção antiquada do positivismo criminológico, cuja base é a repressão disseminada nas políticas criminais que reforçam a ideia de combate à criminalidade pela força, vigilância e punição, desconsiderando todos os problemas sociais historicamente constituídos. No entanto, a história aponta as raízes dos contrastes sociais que se aprofundaram e produziram o atual contexto social de desigualdades e exclusão que marginaliza as pessoas.

Em resposta a este estado de coisas, atualmente está em curso o paradigma da reação social, que é macrocriminológico e macrossociológico, em oposição ao paradigma liberal-individualista, que microcriminológico e despolitizado. Dessa forma, a tendência é que se deixe de olhar para o indivíduo de forma isolada, mas como produto social, cujo processo de inserção no mundo da criminalidade possui múltiplas determinações. Evidentemente, a seletividade dos tipos penais entra nesse esteio, pois, ao desconsiderar os problemas sociais de diferentes ordens, apenas repreende e pune, agravando a situação.

Diante disso, as esferas normativas, judiciárias e executivas começaram a apresentar um ponto em comum em relação aos delitos de menor potencial ofensivo, a saber, diminuir os custos da criminalização, considerando que o direito penal máximo não funciona, apenas estigmatiza e discrimina. A criminologia Crítica, nesse sentido, consiste na crítica, em si mesma, ao direito penal máximo.

Mais direcionado ao tema deste artigo, cabe ressaltar os dados divulgados pelo Infopen sobre os presídios brasileiros, os quais mostram que "25\% dos crimes pelos quais os homens respondem estão relacionados ao tráfico" (INFOPEN, 20 I 4, p. 70).

Entretanto, o Instituto Sou da Paz, ${ }^{9}$ com base nos Inquéritos Policiais e Corregedoria da Polícia Judiciária, bem como do Núcleo de Estudos da Violência da USP, evidencia que $67,7 \%$ das pessoas flagradas com maconha foram encarceradas por tráfico, devido ao porte de menos de 100 gramas, sendo que, desses indivíduos, I 4\% portavam menos de 10 gramas da droga. O estudo informa ainda que " $62,17 \%$ dos traficantes presos no País exerciam atividade remunerada na ocasião do flagrante; 94,3\% não pertenciam a organizações criminosas; e 97\% nem sequer portava algum tipo de arma. Ou seja, eram ou microtraficantes ou usuários" (INSTITUTO SOU DA PAZ, 20 I 4).

Disponível em: http://www.soudapaz.org/o-que-fazemos/materia/67-7-dos-presos-portrafico-de-maconha-tinham-menos-de- 100-gramas-da-droga Acessado em 7/I2/20 5. 
UM DEBATE SOBRE A DESCRIMINALIZAÇÃO DA MACONHA SOB O ENFOQUE DA CRIMINOLOGIA CRÍTICA E A AUDIÊNCIA DE CUSTÓDIA COMO FERRAMENTA CONTRA A PRISÃO CAUTELAR

As descrições e estatísticas divulgadas pelo Instituto conferem com os dados de um estudo sobre o tráfico de drogas na Justiça Criminal do Rio de Janeiro e de Brasília, publicados na Revista Jurídica, de jun./set. de 2009, foram citadas pelo ministro Gilmar Mendes durante o julgamento do Recurso Extraordinário n ${ }^{\circ} 635.659 / \mathrm{SP} .{ }^{10}$ Conforme o ministro, as 730 sentenças condenatórias, analisadas durante o período de outubro de 2006 a maio de 2008, mostraram o seguinte:

por volta de $80 \%$ das condenações decorreram de prisões em flagrante, na maioria das vezes realizadas pela polícia em abordagem de suspeitos na rua (82\% dos casos), geralmente sozinhos (cerca de 60\%) e com pequena quantidade de droga (inferiores al00g). Outro dado interessante é que, em apenas I,8\% dos casos da amostra, houve menção ao envolvimento do acusado com organizações criminosas. A pesquisa constatou, também, uma considerável presença de jovens e adolescentes nas ocorrências. A maioria dos apreendidos (75,6\%) é composta por jovens na faixa etária entre 18 e 29 anos. Verificou-se, ainda, que $62,1 \%$ das pessoas presas responderam que exerciam alguma atividade remunerada - formal ou informal. Revela a pesquisa, também, que $57 \%$ das pessoas não tinham nenhum registro em sua folha de antecedentes (RE $\left.n^{\circ} .635 .659 / \mathrm{SP}\right)$.

Todas essas pessoas devem ser incriminadas e presas, mesmo em face de cometerem um crime de menor potencial ofensivo?

Um fenômeno social sintomático não pode passar despercebido pelas autoridades: no Brasil, um total de I,5 milhões de pessoas usa maconha todos os dias. O Instituto Nacional de Políticas Públicas do Álcool e Outras Drogas da Universidade Federal de São Paulo apontou que 470 mil adolescentes com idade entre 14 e 18 anos usaram maconha em 2014; outros 600 mil, ou 4\% da população, disseram que já experimentaram a droga alguma vez na vida (UNIFESP, 20I5). Será que a nossa juventude deve ser vista como criminosa por fazer uso de um entorpecente que não produz diretamente danos sociais a outras pessoas?

\footnotetext{
10 "Trata-se de recurso extraordinário, com repercussão geral, em que se alega a inconstitucionalidade do artigo 28 da Lei $n^{\circ}$. I 1.343/2006, que define como crime 'adquirir, guardar, tiver em depósito, transportar ou trouxer consigo, para consumo pessoal, drogas sem autorização ou em desacordo com determinação legal ou regulamentar', com sujeição às seguintes penas: 'I - advertência sobre os efeitos das drogas; II - prestação de serviços à comunidade; III - medida educativa de comparecimento a programa ou curso educativo."' Disponível em: http://www.stf.jus.br/arquivo/cms/noticiaNoticiaStf/anexo/RE635659.pdf Acessado em 12/5/2016.
} 
Na próxima seção, analisa-se o problema da descriminalização da maconha à luz do Recurso Extraordinário RE n 635.659/SP, considerando-se os discursos e os votos dos ministros do STF Gilmar Mendes, Luís Roberto Barroso e Edson Facchin, mas procurando ir além da análise jurídica da questão com o apoio da visão de alguns especialistas de outras áreas para enriquecer o debate.

\section{DEBATE SOBRE A DESCRIMINALIZAÇÃO DA MACONHA NO RECURSO EXTRAORDINÁRIO N ${ }^{\circ} 635.659 / \mathrm{SP}$}

A repercussão geral do Recurso Extraordinário n 635.659/SP, que tramita no STF, a despeito do preconceito e pouco debate público, ganhou destaque pela defesa incontestável dos ministros Gilmar Mendes, Luís Roberto Barroso e Edson Facchim, em prol da descriminalização da maconha para uso próprio, que consideraram inconstitucional o acautelamento dos usuários, apontando os problemas sociais decorrentes dos danos sociais. "A criminalização da posse de drogas 'para consumo pessoal' afeta o direito ao livre desenvolvimento da personalidade, em suas diversas manifestações" (RE n . 635.659/SP).

Esse tópico faz uma análise dos argumentos dos ministros, procurando evidenciar a problemática da descriminalização de um ponto de vista que envolve as múltiplas determinações, isto é, os diferentes fatores - sociais, morais, políticos, culturais etc. que precisam ser considerados para uma análise jurídica.

Para fins de conceituação e manutenção do debate sobre a descriminalização da maconha no âmbito jurídico, o termo descriminalização precisa ser definido. Para tanto, nas palavras do ministro Gilmar Mendes (RE n 635.659/SP):

descriminalização, termo comumente utilizado para descrever a exclusão de sanções criminais em relação à posse de drogas para uso pessoal. Sob essa acepção, embora a conduta passe a não ser mais considerada crime, não quer dizer que tenha havido liberação ou legalização irrestrita da posse para uso pessoal, permanecendo a conduta, em determinadas circunstâncias, censurada por meio de medidas de natureza administrativa.

O ministro Gilmar Mendes," no Recurso Extraordinário n 635.659/SP, apontou dados da Revista Jurídica, de jun./set. de 2009, os quais mostram que os jovens são os principais afetados pelo acautelamento. Segundo os dados, das 730 sentenças condenatórias, 75,6\% eram compostas por jovens na faixa etária entre os I 8 e 29 anos.

\footnotetext{
11"Recurso Extraordinário n 635.659 /SP. Disponível em: http://www.stf.jus.br/arquivo/cms/noticiaNoticiaStf/anexo/RE635659.pdf Acessado em 12/5/2016.
} 
UM DEBATE SOBRE A DESCRIMINALIZAÇÃO DA MACONHA SOB O ENFOQUE DA CRIMINOLOGIA CRÍTICA E A AUDIÊNCIA DE CUSTÓDIA COMO FERRAMENTA CONTRA A PRISÃO CAUTELAR

Sobre esse fenômeno, cabe acrescentar a contribuição de Zaccone (201 I , pp. 6364), em que aponta que os encarcerados criminais são "recrutados", em regra, entre as classes mais baixas da sociedade. A intervenção repressiva, dessa forma, se dá por meio da polícia que incide com mais força em determinados grupos que estão mais expostos, especialmente no combate às drogas, que atinge com muita força a juventude pobre e negra (ARGÜELO; MURARO, 20 I 5).

É comum que pessoas que tenham consigo determinada quantidade de maconha, se forem de camadas sociais mais baixas, sejam enquadradas pela polícia e pelo judiciário como traficantes, ao passo que se forem de camadas abastadas, são frequentemente vistas como usuárias.

Ainda nesse contexto, Rocha (2013) ressalta que, historicamente, sempre houve a distinção de usuário e traficante, o que oferece margem para que se coloquem nas classes sociais mais abastadas jovens como usuários e os mais pobres como traficantes. Não é possível negar a existência da criminalização da pobreza como elemento político e ideológico, pois o usuário consegue provar que tem condições financeiras para obter a droga para seu uso, quem não pode prová-las é considerado traficante.

Os dados citados pelo ministro Gilmar Mendes apresentam apenas uma faixa etária, dos 18 aos 29 anos, cuja criminalização pelo uso dessa droga, pode representar um problema sem solução em caso de flagrante, considerando-se que a situação pode piorar sob a égide dos argumentos que defendem o rebaixamento da idade de imputabilidade penal, acentuando as arestas da aparência e diluição das fronteiras do real para mitificar uma das principais contradições do sistema capitalista, que afeta, sobretudo, os adolescentes e os jovens, que são mais vulneráveis diante de diferentes fatores sociais que precarizam a vida.

Os ministros defendem que a criminalização é indevida, uma vez que as consequências do uso de drogas não iriam além da mera lesão pessoal ao usuário. Ademais, a criminalização fere o princípio constitucional do direito ao livre desenvolvimento da personalidade e também das manifestações. Nas palavras do ministro Gilmar Mendes:

Assim, tenho que a criminalização da posse de drogas para uso pessoal é inconstitucional, por atingir, em grau máximo e desnecessariamente, o direito ao livre desenvolvimento da personalidade, em suas várias manifestações, de forma, portanto, claramente desproporcional. (Recurso Extraordinário nº. 635.659/SP).

É o que também entende o ministro Luís Roberto Barroso ${ }^{12}$, que, no julgamento do

\footnotetext{
12“BARROSO, Luís Roberto. RE n. 635.659/SP. Descriminalização do porte de drogas para consumo próprio: anotações para o voto oral do Ministro Luís Roberto Barroso. Disponível em: http://s.conjur.com.br/dl/leia-anotacoes-ministro-barroso-voto.pdfAcessado em 12/5/20 6.
} 
Recurso, destacou a necessidade de se olhar o problema das drogas sob outra perspectiva: "não havendo lesão a bem jurídico alheio, a criminalização do consumo de maconha não se afigura legítima”. Pelo contrário, como afirma o ministro, viola três princípios, a saber:

I. Violação ao direito de privacidade, um direito fundamental protegido pelo art. $5^{\circ}, X$, da Constituição; 2. Violação à autonomia individual, que fere o princípio de autodeterminação e a liberdade (valor fundamental nas sociedades democráticas); 3. Violação ao princípio da proporcionalidade, tendo em vista que sendo o consumo da maconha um ato individual, que vai contra o princípio da lesividade, no qual obsta que para uma conduta ser tipificada como criminosa exige a ofensa a um bem jurídico alheio.

O ministro Gilmar Mendes, por sua vez, reconheceu a necessidade de previsão de critérios mais objetivos para tratamento do assunto. Em suas palavras:

padrão de abordagem é quase sempre o mesmo: atitude suspeita, busca pessoal, pequena quantidade de droga e alguma quantia em dinheiro. Daí pra frente, o sistema repressivo passa a funcionar de acordo com o que o policial relatar no auto de flagrante, já que a sua palavra será, na maioria das vezes, a única prova contra o acusado. Não se está aqui a afirmar que a palavra de policiais não mereça crédito. $\bigcirc$ que se critica é deixar exclusivamente com a autoridade policial, diante da ausência de critérios objetivos de distinção entre usuário e traficante, a definição de quem será levado ao sistema de Justiça como traficante, dependendo dos elementos que o policial levar em consideração na abordagem de cada suspeito. (RE $n^{\circ}$. 635.659/SP).

excerto mostra que o ministro Gilmar Mendes tocou num ponto fulcral que merece toda a atenção das políticas criminais, qual seja, o fato de a triagem dos casos serem feitas, antes, pela polícia - pelo sistema repressivo - sem critérios objetivos, senão aqueles conforme a abordagem de cada pessoa e do que é relatado pelos policiais. As provas são colhidas pelos policiais e servem para condenar as pessoas a priori, pois, normalmente, o juiz tende a acatar.

No mesmo sentido, afirmou o ministro Luís Roberto Barroso ${ }^{13}$ :

É preciso estabelecer um critério por alguns motivos óbvios. O primeiro, naturalmente, é diminuir a discricionariedade judicial e uniformizar a aplicação da lei, evitando que a sorte de um indivíduo fique ao sabor do policial ou do juiz ser mais liberal ou mais severo. O segundo, mais importante ainda, é que a inexistência de um parâmetro objetivo não é neutra. Ela produz um impacto discriminatório que é perceptível a olho nu e destacado por todas as pessoas que

\footnotetext{
13،BARROSO, Luís Roberto. RE 635.659/SP. Descriminalização do porte de drogas para consumo próprio: anotações para o voto oral do Ministro Luís Roberto Barroso. Disponível em: http://s.conjur.com.br/dl/leia-anotacoes-ministro-barroso-voto.pdfAcessado em 12/5/2016.
} 
UM DEBATE SOBRE A DESCRIMINALIZAÇÃO DA MACONHA SOB O ENFOQUE DA CRIMINOLOGIA CRÍTICA E A AUDIÊNCIA DE CUSTÓDIA COMO FERRAMENTA CONTRA A PRISÃO CAUTELAR

lidam com o problema: os jovens de classe média para cima, moradores dos bairros mais abonados, como regra, são enquadrados como usuários; os jovens mais pobres e vulneráveis, que são alvo preferencial das forças de segurança pública, são enquadrados como traficantes.

ministro Barroso propôs um critério objetivo para ser utilizado na diferenciação entre o usuário e o traficante: a posse de até 25 gramas de maconha ou seis plantas fêmeas seria considerado porte para uso pessoal. Tal parâmetro seria utilizado até que o Congresso legislasse sobre o tema de modo definitivo. $\bigcirc$ ministro ressalvou, porém, que o magistrado, em cada caso, poderia considerar outros fatores para caracterizar uma pessoa flagrada com droga como usuária ou traficante. Para tanto, é necessário considerar a antinomia contida na Lei $n^{\circ}$ I I.343, de 2006, que "conferiu tratamento distinto aos diferentes graus de envolvimento na cadeia do tráfico (art. 33, § $4^{\circ}$ ), mas não foi objetiva em relação à distinção entre usuário e traficante. Na maioria dos casos, todos acabam classificados simplesmente como traficantes" (RE n 635.659/SP).

O ministro Gilmar Mendes, ${ }^{14}$ por sua vez, relacionou os países, onde, hoje, a posse para o consumo não é considerada crime, distinguindo entre tráfico e uso. Ele elaborou a tabela a partir dos dados coletados pelo Transnational Institute e Colectivo Estudios Drogas y Derecho (CEDD) e pelo European Legal Database on Drugs/European Monitoring Center for Drugs and Drugs Addiciton, (emcdda.europa.eu/elddm, 15/8//5), conforme segue.

\begin{tabular}{|c|c|c|}
\hline País & Alternativas à criminalização & Critérios de distinção \\
\hline Argentina & Sem medidas administrativas & Interpretação do juiz \\
\hline Bolívia & Tratamento compulsório & $\begin{array}{c}\text { Uso equivalente a 48h } \\
\text { de consumo }\end{array}$ \\
\hline Chile & Medidas administrativas & Interpretação do juiz \\
\hline Colômbia & Sem medidas administrativas & $\begin{array}{c}\text { 20g de maconha, } 5 g \text { de } \\
\text { haxixe, Ig de cocaína }\end{array}$ \\
\hline Equador & Sem medidas administrativas & $\begin{array}{c}\text { I0g de cannabis, } 2 g \\
\text { de pasta base de cocaína } \\
\text { IOg de cannabis, 2g de } \\
\text { cocaína, heroína e } \\
\text { derivados de opiáceos }\end{array}$ \\
\hline Paraguai & Tratamento compulsório & $\begin{array}{c}\text { 8g de maconha, } 5 \mathrm{~g} \text { de } \\
\text { pasta de cocaína, } 250 \mathrm{~g} \\
\text { de ectasy }\end{array}$ \\
\hline
\end{tabular}

14“http://www.stf.jus.br/arquivo/cms/noticiaNoticiaStf/anexo/RE635659.pdfAcessado em $13 / 5 / 2016$ 


\begin{tabular}{|c|c|c|}
\hline Uruguai & Sem medidas administrativas & $40 \mathrm{~g}$ de maconha por mês \\
\hline Costa Rica & Sem medidas administrativas & Interpretação do juiz \\
\hline Honduras & Internação compulsória & Interpretação do juiz \\
\hline Jamaica & $\begin{array}{l}\text { Somente cannabis. } \\
\text { Sem medidas administrativas }\end{array}$ & $\begin{array}{l}2 \text { onças (cerca de } 57 \mathrm{~g} \text { ) de } \\
\text { maconha, } 2.8 \mathrm{~g} \text { de cocaína, } \\
\text { heroína e morfina }\end{array}$ \\
\hline México & Sem medidas administrativas & $\begin{array}{c}5 g \text { de cannabis, } 2 g \text { de Ópio, } \\
0.5 g \text { de cocaína. }\end{array}$ \\
\hline Alemanha & $\begin{array}{l}\text { A lei permite a não instauração } \\
\text { de processo criminal }\end{array}$ & $\begin{array}{c}\text { Entre } 6 \text { e I } 5 \mathrm{~g} \text { de maconha } \\
\text { (14 estados fixaram em 6g). } \\
\text { Cocaína e heroína: I a } 2 \mathrm{~g} \\
\text { (prática judicial) }\end{array}$ \\
\hline Bélgica & $\begin{array}{c}\text { Apenas cannabis. } \\
\text { Sem medidas administrativas }\end{array}$ & $3 g$ de resina ou da erva \\
\hline Espanha & Medidas administrativas & $\begin{array}{c}25 \mathrm{~g} \text { de haxixe, } 100 \mathrm{~g} \text { de } \\
\text { Cannabis, } 3 \mathrm{~g} \text { de heroína, } \\
7.5 \mathrm{~g} \text { de cocaína }\end{array}$ \\
\hline Holanda & Sem medidas administrativas & $\begin{array}{l}\text { 5g de maconha, } \\
0.5 \mathrm{~g} \text { de cocaína }\end{array}$ \\
\hline Itália & Medidas administrativas & $\begin{array}{c}\text { I g de THC, } 0.25 \mathrm{~g} \text { de } \\
\text { heroína e } 0.75 \mathrm{~g} \text { de cocaína }\end{array}$ \\
\hline Lituânia & Medidas administrativas & $\begin{array}{c}5 g \text { de maconha, } 0.2 \\
\text { de heroína, } 0.2 \text { de cocaína }\end{array}$ \\
\hline Luxemburgo & $\begin{array}{c}\text { Apenas cannabis. } \\
\text { Medidas administrativas }\end{array}$ & Interpretação do juiz \\
\hline Portugal & Medidas administrativas & $\begin{array}{c}\text { 25g de maconha } \\
\text { (equivalente a I0 } \\
\text { doses diárias), Ig de } \\
\text { ecstasy e } 2 \mathrm{~g} \text { de cocaína } \\
\end{array}$ \\
\hline Países Baixos & Sem medidas administrativas & $\begin{array}{l}5 \mathrm{~g} \text { de maconha e } 0.5 \mathrm{~g} \\
\text { de heroína ou cocaína }\end{array}$ \\
\hline República Checa & Medidas administrativas & $\begin{array}{c}\text { I5g de maconha, } \\
\text { dependendo } \\
\text { da pureza, I g de cocaína, } \\
4 \text { tabletes de ecstasy }\end{array}$ \\
\hline
\end{tabular}

Fonte: Ministro Gilmar Mendes, Recurso Extraordinário n 635.659/SP. Disponível em: http://www.stf.jus.br/arquivo/cms/noticiaNoticiaStt/anexo/RE635659.pdf 
UM DEBATE SOBRE A DESCRIMINALIZAÇÃO DA MACONHA SOB O ENFOQUE DA CRIMINOLOGIA CRÍTICA E A AUDIÊNCIA DE CUSTÓDIA COMO FERRAMENTA CONTRA A PRISÃO CAUTELAR

O propósito, ao se descriminalizar a maconha, é fazer com que o usuário deixe de ser visto pela sociedade e pelo Estado como criminoso e, se for o caso, passe a ser tratado como dependente, sendo alvo das políticas públicas, e não de punição. As drogas por si mesmas já causam danos sociais e físicos, deve-se dar também um tratamento criminal? Criminalmente, a autolesão que elas provocam é irrelevante, senão para as políticas públicas ligadas à área da saúde.

Nesse sentido, o ministro Edson Facchin, ao proferir seu voto no Recurso Extraordinário, citado alhures, afirmou:

O dependente é vítima e não criminoso germinal. Com base neste quadro fático, o usuário em situação de dependência deve ser encarado como doente. Ao necessitar de tratamento para a superação do vício, é estabelecida ao Estado (e mesmo à sociedade) uma obrigação de fornecer os meios necessários para tanto. ${ }^{15}$

Dessa perspectiva, o Estado deverá apoiá-lo contra o vício e, se for seu desejo, tratálo. Como também, diante do fato, o Estado poderá realizar contrapropaganda para buscar a diminuição do uso, tal qual fez e faz com o cigarro, que não é ilícito, mas cujo uso vem diminuindo gradativamente. Essa redução do consumo de tabaco se deu em razão de forte contrapropaganda e por reconhecimento pelo Estado de que o usuário é dependente, cuja doença causada pelo vício custa caro ao sistema público de saúde. Da mesma forma, o consumo abusivo de bebidas alcoólicas reclama cuidados com o corpo e requer recursos dos cofres públicos para dispor de tratamento para os doentes.

Ora, para o tabaco, que é tão ou mais lesivo à saúde pública que a maconha, não há a criminalização ao seu consumo, e não se cogita que ela ocorra. Entretanto, por qual motivo existe o estigma de que as atuais drogas ilícitas, em especial a maconha, são perigosas? Isso ocorre por uma inversão da própria evidência científica, pois as substâncias que oferecem o maior risco são as substâncias lícitas. $\bigcirc$ álcool, por exemplo, é o que traz o maior número de acidentes de automóvel ou de violência doméstica.

O debate adiante segue os argumentos propostos pelo professor da USP Henrique Soares Carneiro ${ }^{16}$, doutor em História Social e especialista em história da alimentação e das drogas, que faz uma análise sóbria do fenômeno do uso das drogas que extrapola o âmbito jurídico e coloca o leitor diante do contexto histórico e crítico acerca do uso em diferentes circunstâncias, propondo que se reveja o modelo do proibicionismo.

\footnotetext{
${ }^{15} \mathrm{FACCHIN}$, Edson. In.: Leia a íntegra do voto do ministro Fachin sobre descriminalização das drogas. Publicado em 10/9/20 I5. Disponível em: http://jota.uol.com.br/leia-a-integra-do-votodo-ministro-fachin-sobre-descriminalizacao-das-drogas Acessado em 12/4/20 16.

${ }^{16}$ CARNEIRO, Henrique. História do Proibicionismo e do Movimento Antiproibicionista. Disponível em: https://www.youtube.com/watch?v=ZYrKqclpNNY Acessado em 12/4/20 16.
} 
O tabaco é, segundo a Organização Mundial da Saúde (OMS), o maior causador de mortes da humanidade, sendo de cinco milhões de pessoas por ano. Mais de meio bilhão no último século. O professor Henrique Carneiro explicita que é falsa a difusão da ideia de que a proibição das drogas serve para melhorar a saúde pública. Essa tese não se sustenta, pois se pode aplicá-la aos alimentos. Sabidamente, um dos maiores problemas de saúde das sociedades desenvolvidas é de âmbito dietético, sendo eles o açúcar e as gorduras animais, pois a obesidade já atinge metade da população dos países ricos. Assim, se for aplicar o mesmo critério aos alimentos que se aplicam às drogas tidas como ilícitas, em especial à maconha, pode-se dizer que uma pessoa que se alimente inadequadamente está causando um custo para a sociedade e está se prejudicando. Entretanto, não é crível que alguém seja criminalizado pela conduta de se alimentar inadequadamente. Conforme salienta Carneiro, se esse raciocínio não se aplica aos alimentos, por quais critérios deveria ser aplicado às drogas colocadas em lista de ilicitude?

As drogas, como os alimentos, são produtos de ingestão humana. Portanto, constata-se que existe uma esquizofrenia institucional que faz de certas drogas objeto de uma perseguição demonizante, e outras ganham o emblema da felicidade, da alegria e dos bons lucros das empresas que as comercializam, como é o caso das bebidas alcoólicas, do tabaco e dos alimentos embutidos, enlatados etc., que carregam grandes doses de produtos químicos cancerígenos.

Por exemplo, o Brasil é o maior exportador de tabaco do mundo, que é uma das substâncias mais perigosas e venenosas do Planeta. Porém, para a nossa economia, o tabaco foi e é tão salutar que está inscrito em nosso brasão, o qual tem um pé de café e um de tabaco e não se fala em proibir o tabaco. Sobre este, há o controle e a regulamentação da forma e local de uso, mas não o proíbe. Por exemplo, não se usa tabaco em locais fechados para evitar o dano coletivo, deduzindo-se que individualmente cada um assume o risco para a sua saúde. "Até agora não se tem afirmado, por exemplo, que o álcool e o tabaco afetam suficientemente a saúde pública a ponto de legitimar a criminalização de sua venda e consumo." (RE n 635.659/SP). Certamente, pode-se dizer o mesmo da maconha.

Nessa toada, a despeito de muito incipiente a discussão da descriminalização das atuais drogas ilícitas, tendo-se iniciado ainda que timidamente pela maconha no STF, recentemente o proibicionismo e sua eficácia vêm sendo colocados em evidência no Brasil, da mesma forma que em outros países da América do Sul, seguindo uma tendência mundial, já delineada pelas Nações Unidas. $\bigcirc$ uso de algumas drogas tem sofrido alteração no paradigma, conforme as discussões de ex-presidentes de alguns países, os quais reconhecem a necessidades de alterar suas concepções sobre a proibição de drogas atualmente ilícitas, asseverando que tal proibição é um equívoco. Alguns exemplos, o ex-presidente Fernando Henrique Cardoso, César Gavíria na Colômbia, Pepe Mujica, no Uruguai. 
UM DEBATE SOBRE A DESCRIMINALIZAÇÃO DA MACONHA SOB O ENFOQUE DA CRIMINOLOGIA CRÍTICA E A AUDIÊNCIA DE CUSTÓDIA COMO FERRAMENTA CONTRA A PRISÃO CAUTELAR

Nesse âmbito, algumas informações são importantes para demonstrar com clareza que a descriminalização da maconha só traz benefícios e evita os danos sociais aos usuários, tendo em vista que, como explicita o professor Henrique Carneiro, "ninguém morre de uso de maconha, mas muitos óbitos são de balas trocadas no narcotráfico por causa de controle de vendas ou repressão a ela". Nessa lógica, há vários movimentos sociais e até políticos se voltando contra a política proibicionista. Todavia, há o grande desafio de apresentar uma alternativa para o Brasil, na atualidade. Carneiro salienta que a discussão para se atribuir ao usuário o porte de determinada quantia ainda é tímida, pois tem de partir para um modelo de legalização plena.

No tocante a esse aspecto, ele salienta que a legalização plena não significa acessibilidade indiscriminada. Assim, citando o tabaco e o álcool, os quais são legalizados, haveria uma legalização plena, mas com regras. Outro ponto a ser discutido é o de que as formas de regulamentação envolvem a forma de acesso, ao passo que a legalização de outras drogas, em especial a maconha, traria a diminuição potencial do uso de álcool, que muitas vezes não tem sua lesividade levada em consideração.

Diz Carneiro que se houver maconha disponível, a pessoa poderá preferir um cigarro de maconha ao uso de álcool, não ficando sujeita a um padrão monopolístico para o lazer químico ligado ao álcool. Cita-se, para exemplificar essa mudança de paradigma, a Inglaterra, local em que o lazer químico deixou de ser alcoólico e passou a ser de ecstasy, tendo muito menos perturbações, pois as pessoas brigam menos, causam menos acidentes de carro etc. Ressalve-se que não se quer liberar de forma indiscriminada a maconha para qualquer um; pelo contrário, busca-se controle. Qualquer indivíduo poderá ter acesso à maconha, mas não de forma indiscriminada, sem controle do Estado, sem controle de qualidade do produto. É necessário impedir que o usuário tenha acesso a produtos adulterados e de péssima qualidade que, nesse caso sim, são muito danosos ao organismo. O ideal seria o que ocorreu no Uruguai: controle estatal da grande produção e do atacado, fazendo com que o lucro seja integralmente revertido para o interesse social e da saúde pública.

Pondera Carneiro que permitir que a iniciativa privada produza e venda a maconha, apesar de não ser tão ruim quanto ao que ocorre na atualidade com o proibicionismo, não é a melhor saída, pois haveria fomento ao seu consumo, tal qual ocorre com o tabaco e o álcool, tendo em vista que se visaria ao lucro. Nesse diapasão, esse debate do fim do proibicionismo está tomando grande proporção, isto é, liberdade de disposição de si mesmo, disposição do corpo. Entretanto, ainda existe a "maconhofobia" na sociedade. O pior mal da maconha, atualmente, é o contato com o crime, e não a maconha em si. A descriminalização vai permitir acesso controlado e limitado às pessoas que queiram fazer seu uso sem esse contato. A diferença de quem usa maconha de quem não usa é que tem de ficar à sombra de uma perseguição jurídica, policial e cultural.

Outro fator positivo da descriminalização é a diminuição do tráfico. Parece contraditório, mas há certa lógica nisso. Vejamos: Com a descriminalização do porte até 
determinada quantidade de maconha, também seria permitido o cultivo de certo número de plantas para o uso próprio do usuário, como se faz, hoje, no Uruguai. Assim, o usuário não precisaria se dirigir a traficantes para adquirir a droga.

Sobre esse assunto, o ministro Luís Roberto Barroso faz a ressalva de que a referida descriminalização deve ser efetuada paulatinamente, de modo a permitir uma avaliação constante dos resultados de tal medida:

Esta a primeira prioridade: neutralizar, a médio prazo, o poder do tráfico. Para isso, só há uma solução: acabar com a ilegalidade das drogas e regular a produção e a distribuição. Esta ideia foi veiculada em um corajoso artigo de Helio Schwartsman, publicado na Folha de São Paulo de 19.08.20 I 5. É importante o registro, mas não é isto o que está em discussão. $O$ grande problema do direito é que não podemos fazer experimentação em laboratórios para saber se algo funciona ou não funciona. Por isso, temos que atuar aos poucos, passo a passo, testando soluções. ${ }^{17}$

Segundo Thiago Rodrigues (2003), em diversos países, como Austrália e EUA, e no continente Europeu, o proibicionismo não erradicou o consumo, pelo contrário, o mercado negro só cresceu. Isso causou violência e consequências nefastas para usuários que utilizavam substâncias adulteradas e ministradas sem segurança, o que produziu crítica ao proibicionismo dentro dele mesmo. A realidade fez com que médicos, cientistas sociais e outros vissem a guerra às drogas com a erradicação total como intransponível, sem deixar meios alternativos para os que optassem pelo consumo.

Na Europa, por exemplo, para evitar tais problemas, criou-se o que ficou conhecido como política de redução de danos em decorrência do mau uso das drogas e das consequências negativas para o corpo e para a vida social. Para tanto, foi necessário estabelecer uma política de legalização com forte controle estatal, prevendo que "o narcotráfico sucumbiria pela concorrência de um Estado droguista que produzisse e vendesse psicoativos ou que, ao menos, controlasse a comercialização em pontos específicos de venda" (RODRIGUES, 2003, p. 268).

De acordo com o Ministro Gilmar Mendes:

Subjacente ao processo de descriminalização, vem se multiplicando, em muitos países, com o apoio da ONU, a adoção de programas e de práticas que visam mitigar as consequências sociais negativas decorrentes do consumo de drogas psicoativas, legais ou ilegais. A essa prática tem se atribuído a denominação de

\footnotetext{
17BARROSO, Luís Roberto. RE 635.659/SP. Descriminalização do porte de drogas para consumo próprio: anotações para o voto oral do Ministro Luís Roberto Barroso. Disponível em: http://s.conjur.com.br/dl/leia-anotacoes-ministro-barroso-voto.pdfAcessado em 12/5/20 16.
} 
UM DEBATE SOBRE A DESCRIMINALIZAÇÃO DA MACONHA SOB O ENFOQUE DA CRIMINOLOGIA CRÍTICA E A AUDIÊNCIA DE CUSTÓDIA COMO FERRAMENTA CONTRA A PRISÃO CAUTELAR

políticas de redução de danos e de prevenção de riscos. Quando se cogita, portanto, do deslocamento da política de drogas do campo penal para o da saúde pública, está se tratando, em última análise, da conjugação de processos de descriminalização com políticas de redução e de prevenção de danos, e não de legalização pura e simples de determinadas drogas, na linha dos atuais movimentos de legalização da maconha e de leis recentemente editadas no Uruguai e em alguns Estados americanos. (VOTO, RE n. 635.659/SP).

Então, no tocante à redução de danos, essa política não se confunde com o incentivo ao uso, mas tão somente se refere às políticas públicas, para reduzir os efeitos negativos - físicos e sociais -, para propor tratamento e produzir informação contextualizada e propostas educativas. Trata-se, portanto, de uma forma de controle social.

Dessa forma, a redução de danos se aplica à pessoa que faz uso de drogas lícitas, ou não, considerando-se que existem estratégias práticas para usá-las de forma segura e com as condições de controle dos efeitos sobre o usuário. ${ }^{18} \mathrm{O}$ Estado deve estar numa posição horizontal ao usuário, reconhecendo os seus direitos, as formas de uso e o funcionamento da droga para prever o comportamento social, os perigos para a saúde etc., para criar políticas públicas, e não numa posição vertical ou de superioridade para reprimir. A repressão deve ocorrer em relação ao tráfico.

Temos em jogo, portanto, de um lado, o direito coletivo à saúde e à segurança públicas e, de outro lado, o direito à intimidade e à vida privada, que se qualificam, no caso da posse de drogas para consumo pessoal, em direito à autodeterminação. Nesse contexto, impõe-se que se examine a necessidade da intervenção, o que significa indagar se a proteção do bem jurídico coletivo não poderia ser efetivada de forma menos gravosa aos precitados direitos de cunho individual. ( $\left(\mathrm{RE} \mathrm{n}^{\circ}\right.$. 635.659/SP).

O sociólogo Denis Petuco, especialista em redução de danos, explica que, havendo descriminalização, o usuário pode sofrer menos discriminação social e familiar; ter orientação quanto ao cultivo e uso de sua droga, por exemplo, a maconha, em sua própria casa, de modo a evitar contato com traficantes e com outras drogas, além de não contribuir com a violência nem correr riscos. ${ }^{19}$ Ora, se está dentro da legalidade com a maconha, para que buscar a ilegalidade com outras drogas? Para que se expor ao

${ }^{18}$ GORGULHO, Mônica. Drogas: política de redução de danos (Parte | de 5). Entrevista realizada por Marília Gabriela. Disponível em: $<$ https://www.youtube.com/watch?v=T66cL6BnpLg>. Acessado em 16/4/2016.

19 PETUCO, Denis. JC Entrevista Denis Petuco: redução de danos. Disponível em: $<$ https://www.youtube.com/watch?v=8rWwRjjjXgE > . Acessado em 16/4/20 I6. 
contato com traficantes e criminosos perigosos?

Não se dirigindo ao traficante, o usuário deixa de ter contato com o submundo do crime e restringe o acesso a outras drogas que não se quer descriminalizar. Em suma, o usuário de maconha estaria dentro da legalidade e menos vulnerável.

\section{JUVENTUDE E CRIMINALIDADE: AS INFLUÊNCIAS NEGATIVAS DA CULTURADO CONSUMO}

Desde a década de 1960, a juventude tem sido vista como possibilidade, considerando-se as mudanças que produz nos valores e costumes, pelo inconformismo e resistência, pela contestação etc., que são assaz fatores necessários para produzir as mudanças sociais.

Entretanto, hoje está em curso um fenômeno mundial que afeta a juventude em diferentes partes do Planeta: os padrões de comportamento foram incorporados e ajustados à lógica da cultura do consumo. Tal fenômeno tem mostrado que a juventude teve a sua mentalidade moldada pelo valor de mercado. A autonomia e a capacidade de escolha, características da individualidade, foram reduzidas pelos parâmetros do aparato técnico e da vida condicionada à realização pela aquisição de mercadorias.

Conforme o filósofo frankfurtiano Herbert Marcuse (1967), a liberdade foi trocada pelo conforto à medida que os indivíduos se ajustaram aos padrões de consumo e suas regras. Nesse sentido, pode-se dizer que a subjetividade foi incorporada ao aparato, respondendo aos padrões de desempenho, produtividade e sucesso.

A ideia de ostentação ${ }^{20}$ entre os jovens, por exemplo, tornou-se indicador de prestígio, sucesso e vida feliz. Contraditoriamente, uma parte considerável dos jovens se tornou vulnerável pelo estímulo ao consumo, sem possibilidades reais de consumir.

A mercantilização planetária da vida social é uma proposta de realidade e se constitui na promessa de felicidade da sociedade capitalista - enquanto fomentadora de uma ética hedonista -, que disputa o espaço com a fugacidade da vida. A juventude que escapa por entre os dedos precisa ser vivida.

Dessa perspectiva, a sensibilidade juvenil, na atual conjuntura, parece ter introjetado a cultura do consumo e se tornado sensibilidade consumidora em virtude do efêmero e da fragmentação da própria vida, passando a devorar indiscriminadamente bens materiais e imateriais. Esse é o padrão de juventude exigido pela sociedade do consumo.

\footnotetext{
20 'Crime de ostentação' é a principal motivação da entrada de jovens no mundo da criminalidade. A constatação é da Delegacia Especializada do Adolescente (DEA), da Polícia Judiciária Civil, que recebeu até começo de dezembro de 2014, mais de 617 menores em situação de flagrante." Disponível em: <http://www.midianews.com.br/cotidiano/ostentacao-social-motiva-entradade-jovens-na-criminalidade-diz-delegado/220347> . Acessado em 25/5/20 I 6.
} 
UM DEBATE SOBRE A DESCRIMINALIZAÇÃO DA MACONHA SOB O ENFOQUE DA CRIMINOLOGIA CRÍTICA E A AUDIÊNCIA DE CUSTÓDIA COMO FERRAMENTA CONTRA A PRISÃO CAUTELAR

A contradição reside nesse processo. "Nas condições de um padrão de vida crescente, o não-conformismo com o próprio sistema parece socialmente inútil, principalmente quando acarreta desvantagens econômicas e políticas tangíveis e ameaça o funcionamento suave do todo" (MARCUSE, 1967, p. 24). Vivemos numa sociedade ajustada e, portanto, acrítica em relação o modelo de cultura do consumo.

A ideia, em relação ao sistema, é introjetar e/ou internalizar nos indivíduos os valores da cultura do consumo e implantar gradualmente um processo de administração total da vida, já que precondicionar a subjetividade garante a reprodução do capital e das próprias forças produtivas que o sustentam. $\bigcirc$ fenômeno da reprodução e perpetuação dos controles externos depende da internalização da repressão. "Introjeção sugere uma variedade de processos relativamente espontâneos pelos quais um Eu (ego) transfere o 'exterior' para o interior" (MARCUSE, 1967, p. 30), transformando o indivíduo resistente em veículo da cultura dominante.

Um pressuposto fundamental para se compreender a dinâmica do sistema capitalista é o de que a luta pela permanência e estabilidade do capital não está sendo travada somente nas esferas política e econômica, mas, sobretudo, na esfera cultural e voltada para o domínio da subjetividade.

A contribuição dessa análise dos valores sociais disseminados pela cultura do consumo fornece alguns elementos que permitem compreender algumas das possíveis causas para o crescente número de jovens infratores. A pobreza e a ausência da satisfação das necessidades mais básicas, a falta de assistência e de educação, os apelos da mídia ao consumo etc. tornam-nos mais suscetíveis à criminalidade.

Ora, existe um paradoxo na própria ideia de juventude diante das transformações sociais. De um lado, os jovens querem "curtir a vida", consumir efusivamente, parecerem sempre jovens cheios de vitalidade e possibilidade etc., pois a juventude é mesmo um valor a ser vivenciado. Por outro, é evidente que nem todos os jovens podem desfrutar dessa mesma perspectiva por estarem excluídos da riqueza socialmente produzida. Socialmente, os pobres são percebidos como problema, se considerado que a juventude é um período de instabilidade, incerteza e vulnerabilidade (PEREIRA, 20 I 5), chegando a ser caracterizada como perigo social, tendo em vista que a inclusão pela via da cultura do consumo esbarra na impossibilidade de consumir o que cria e alimenta a promessa de status e integração num grupo social.

Como fica a condição das pessoas que introjetaram a cultura do consumo, mas em determinados momentos são afetados por problemas estruturais do próprio sistema como crises econômicas, que geram o desemprego; a exclusão; a falta de oportunidade e acesso; a falta de perspectiva? Criou-se a comunidade do consumo, mas como reproduzir a sua existência em meio à crise do capital? Os jovens aderiram à promessa de felicidade pelo consumo, mas como sustentá-la sem o trabalho?

A Organização Internacional do Trabalho (2009) apontou que a fórmula para a vulnerabilidade juvenil está na soma de fatores como a desigualdade educacional e déficit de emprego formal, que, juntos, geram a falta de perspectivas. Certamente são fatores 
que geram a vulnerabilidade e podem conduzir os jovens à infração, num contexto em que o estímulo ao consumo de todos os tipos de bens, materiais e imateriais, não podem ser satisfeitos pelas vias legais da compra.

Abaixo, seguem os dados divulgados pela Organização Internacional do Trabalho (OIT/PREJAL), agenda hemisférica 2006-20I5, sobre o déficit do emprego formal e vulnerabilidade juvenil, que envolvem variáveis como desemprego, ocupação informal, déficit de emprego formal, inativos que não estudam, desempregados que não estudam, jovens que não estudam nem trabalham. Conforme tabela:

\begin{tabular}{|c|c|c|}
\hline \multicolumn{3}{|c|}{ Déficit do emprego formal e vulnerabilidade juvenil - Brasil 2006} \\
\hline Item & Valores absolutos & $\begin{array}{c}\text { Valores em relação } \\
\text { ao total em \% }\end{array}$ \\
\hline Total & 34.709 .467 & 100,0 \\
\hline I - Desempregados & 3.938 .951 & 11,3 \\
\hline II - Ocupados na informalidade & I I.043.687 & 31,8 \\
\hline III - Déficit de emprego formal $=I+\|$ & | 4.982.638 & $\begin{array}{r}43,2 \% \text { do total dos } \\
\text { jovens } 67.5 \% \text { da PEA }\end{array}$ \\
\hline IV - Inativos que não estudam & 4.337 .569 & 12,5 \\
\hline V - Desempregados que não estudam & 2.202 .719 & 6,3 \\
\hline $\begin{array}{l}\mathrm{VI}-\text { Jovens que não estudam nem } \\
\text { trabalham }=\mathrm{IV}+\mathrm{V}\end{array}$ & 6.540 .288 & 18,8 \\
\hline $\begin{array}{l}\text { VII - Índice de vulnerabilidade Juvenil } \\
=I+I I+V I-V=I I I+I V\end{array}$ & 19.320.207 & 55,7 \\
\hline
\end{tabular}

Fonte: Elaborado pela OIT/PREJAL, a partir de microdados da IBGE/PNAD de 2006; Brasil como um todo, até mesmo com norte rural.

Sabidamente, as crises do sistema capitalista são constantes e variam de intensidade, afetando toda a cadeia produtiva e produzindo consequências societárias drásticas, sobretudo para os trabalhadores. "Não existe capitalismo sem crises", elas são cíclicas, e o Brasil está experimentando, atualmente, uma crise sistêmica. "A crise sistêmica se manifesta envolvendo toda a estrutura da ordem do capital." (NETTO, 20 I 2, p. 4I 5).

fato é que tal crise também produz desemprego estrutural e exige constante 
UM DEBATE SOBRE A DESCRIMINALIZAÇÃO DA MACONHA SOB O ENFOQUE DA CRIMINOLOGIA CRÍTICA E A AUDIÊNCIA DE CUSTÓDIA COMO FERRAMENTA CONTRA A PRISÃO CAUTELAR

reestruturação do mundo do trabalho, sem deixar de ressaltar que uma de suas marcas é o desemprego e a informalidade. Os padrões de sociabilidade passam por um turbilhão e, diante disso, as camadas sociais menos protegidas sofrem diretamente as consequências.

Tais segmentos compreendem universos heterogêneos, desde aposentados com pensões miseráveis, crianças e adolescentes sem qualquer cobertura social, migrantes e refugiados, doentes estigmatizados (recordem-se os aidéticos pobres) até trabalhadores expulsos do mercado de trabalho (formal e informal). (NETTO, 2012, p. 4I8).

Conforme dados do Instituto Brasileiro de Geografia e Estatística (IBGE), ${ }^{21}$ no $1^{\circ}$ trimestre de 2016, a taxa de desemprego chegou a 10,9\%, com base na Pesquisa Nacional por Amostra de Domicílio Contínua (PNAD Contínua), realizada em sete capitais brasileiras, envolvendo 38.500 domicílios. Em fevereiro de 2016, a taxa de desemprego entre os jovens chegou a 20,8\%, considerando-se a faixa etária de I 8 a 24 anos, segundo os dados da Pesquisa Mensal de Emprego (PME) divulgado pelo IBGE. Em todos os setores de produção houve aumento na taxa de desemprego, mas é relevante ressaltar que foi maior entre os jovens.

Hoje, o trabalho ${ }^{22}$ como categoria fundamental não é garantido para todos. Ainda há de se refletir sobre o problema da reestruturação produtiva do mercado de trabalho, que exige cada vez mais qualificação. São fatores que afetam as famílias, sobretudo os jovens.

Numa análise macrossociológica, por sua vez, múltiplas determinações podem causar o fenômeno da criminalidade; entretanto, a totalidade não pode deixar de ser vista como causa. Afinal, o projeto societário do capitalismo tem mostrado o esgotamento das possibilidades civilizatórias, cujos reflexos são as contradições sociais e a barbárie.

A próxima seção procura evidenciar que, enquanto não ocorrer o processo de

\footnotetext{
${ }^{21}$ Disponível em:

http://www.ibge.gov.br/home/estatistica/indicadores/trabalhoerendimento/pme/pmemet2.sht m Acessado em 17/5/2016.

${ }^{22} V$ er as "Notas metodológicas": "O conceito fundamental é o de trabalho: significa a ocupação econômica remunerada em dinheiro, produtos ou outras formas não monetárias, ou a ocupação econômica sem remuneração, exercida pelo menos durante 15 horas na semana, em ajuda a membro da unidade domiciliar em sua atividade econômica, ou a instituições religiosas beneficentes ou em cooperativismo ou, ainda, como aprendiz ou estagiário." (IBGE, 20|6). Disponível em:

http://www.ibge.gov.br/home/estatistica/indicadores/trabalhoerendimento/pme/pmemet2.sht m Acessado em 17/5/2016.
} 
descriminalização da maconha, visto como tipo penal de menor potencial ofensivo, a Audiência de Custódia pode ser uma importante ferramenta para a redução da prisão cautelar.

\section{A AUDIÊNCIA DE CUSTÓDIA COMO FERRAMENTA PARA A REDUÇÃO DA PRISÃO CAUTELAR}

No início do ano de 20 I 5, o Conselho Nacional de Justiça (CNJ) lançou um projeto para a implementação da Audiência de Custódia em todos os estados da Federação, progressivamente, buscando a utilização mais adequada das medidas cautelares em face do sistema de justiça criminal.

A pessoa presa em flagrante delito é apresentada 24 horas após a comunicação de sua prisão ao magistrado competente, em observância ao disposto no artigo $7^{\circ}$, item 5 , do Decreto no 678, ${ }^{23}$ de 6 de novembro de 1992, que promulgou a Convenção Americana sobre Direitos Humanos (Pacto de San José da Costa Rica, de 22 de novembro de 1969).

A Audiência de Custódia/Apresentação é um instituto que se relaciona à prisão em flagrante. ${ }^{24}$ Essa espécie de prisão ocorre quando o delito ainda está sendo praticado ou acabou de acontecer, sendo dispensável qualquer tipo de autorização judicial.

Nesse contexto, pode-se conceituar o novo instituto da Audiência de Custódia como a imediata apresentação da pessoa presa ou encarcerada ao juiz competente, para a verificação da regularidade legal do ato, bem como a necessidade, ou não, de manter o indivíduo preso, diante da possibilidade de deferimento da liberdade provisória.

Está previsto no artigo $5^{\circ}$, inciso $L X I$, da Constituição Federal, que "ninguém será preso senão em flagrante delito ou por ordem escrita e fundamentada de autoridade judiciária competente, salvo nos casos de transgressão militar ou crime propriamente militar, definidos em lei".

Conforme o projeto de Audiência de Custódia, após a prisão, o indivíduo é apresentado à autoridade competente, que lavra o auto de prisão em flagrante, com o depoimento de todos os envolvidos no recolhimento do flagrado. Nesse momento, caberá ao magistrado converter o flagrante em prisão preventiva ou conceder a liberdade ao agente acusado da prática do crime.

Diante desse quadro, a Audiência de Custódia é uma resposta possível para

\footnotetext{
${ }^{23}$ Disponível em: http://www.planalto.gov.br/ccivil_03/decreto/D0678.htm Acessado em 26/5/20I5.

${ }^{24}$ O termo deriva do latim flagrare, que significa queimar, arder.
} 
UM DEBATE SOBRE A DESCRIMINALIZAÇÃO DA MACONHA SOB O ENFOQUE DA CRIMINOLOGIA CRÍTICA E A AUDIÊNCIA DE CUSTÓDIA COMO FERRAMENTA CONTRA A PRISÃO CAUTELAR

minimizar os impactos negativos do encarceramento de presos provisórios, consistindo numa ferramenta eficiente na preservação das garantias constitucionais do indivíduo preso.

As Audiências de Custódia passaram a ser realizadas na capital do estado do Tocantins, ${ }^{25}$ no mês de agosto de 2015 , e apresentaram, num primeiro levantamento, o seguinte percentual de deferimento de liberdades provisórias, referentes ao total de prisões em flagrante realizadas: agosto de 2015 (73\%); setembro de 2015 (56\%); e outubro de $2015(54 \%)$.

Tais números podem ser diretamente confrontados com o percentual de liberdades provisórias concedidas no período anterior ao da implantação da Audiência de Custódia, para que haja um processo de apuração em que se verifique sua eficiência na preservação das garantias constitucionais. No caso de jovens usuários, presos por porte de pequena porção de maconha, a Audiência de Custódia pode evitar que sejam acautelados junto a outros tipos penais com grau de periculosidade maior, bem como impede que haja contato entre diferentes perspectivas do ato infracional.

Portanto, considera-se a audiência uma ferramenta importante para esse específico tipo penal, até que o Recurso Extraordinário n 635.659/SP, que está em julgamento no Supremo Tribunal Federal, seja concluído, conforme os votos proferidos pelos ministros Luís Roberto Barroso, Gilmar Mendes e Eduardo Fachin, que demonstram com muita propriedade as vantagens da descriminalização da maconha para uso próprio.

Para além da análise da descriminalização, que ainda está em debate, a Audiência de Custódia pode minimizar os impactos negativos da superlotação e do contato do indivíduo acautelado pela prática desse tipo penal com outros presos condenados perigosos. A ideia é evitar que o cidadão, que não seja criminoso, venha a ser preso provisório, diminuindo a população carcerária e os altos gastos para o Estado em relação ao seu custeio. Com a economia conseguida, o Estado poderá despender de melhor forma os recursos para melhorar as condições dos presídios e investir na ressocialização dos condenados.

Conforme salientado pelo ministro Gilmar Mendes, em seu voto no Recurso Extraordinário n 635.659/SP, acerca da importância da audiência de custódia:

[...] a avaliação da qualidade da prisão em flagrante pelo tráfico de drogas e da

${ }^{25}$ Em 2 de julho de 2015, o Pleno do Tribunal de Justiça do Estado do Tocantins aprovou a Resolução $n^{\circ}$. 17, por meio da qual foi implantada a audiência de custódia, inicialmente na comarca de Palmas. A Portaria n. I 540/20 I 5 da PRESIDÊNCIA/GABJAPRE, de 24 de abril de 2015, designou como signatário Yuri Anderson Pereira Jurubeba, para auxiliar no projeto de implantação. 


\begin{abstract}
necessidade de sua conversão em prisão preventiva deve ser objeto de especial análise pelo Poder Judiciário. A apresentação do preso ao juiz, em curto prazo, para que o magistrado possa avaliar as condições em que foi realizada a prisão e se é de fato imprescindível a sua conversão em prisão preventiva é providência imprescindível. Trata-se de medida já incorporada ao direito interno, prevista no art. 7.5 do Pacto de São José da Costa Rica, mas que ainda encontra alguma resistência em sua aplicação, por razões atinentes, sobretudo, a dificuldades operacionais. A apresentação de presos ao juiz é uma realidade em praticamente todos os países democráticos. A simples tradição não sustenta, portanto, a nossa práxis atual.
\end{abstract}

Tendo esse raciocínio em foco, como medida democrática que amplia o estado democrático de direito e resguarda os Direitos Humanos, ao se descriminalizar o porte de determinada quantia de maconha, haveria diminuição de injustiças, pois os critérios para a caracterização de usuário seriam mais objetivos, já que atualmente os do artigo 28 da Lei n | I.343, de 2006, não o são. A tradição, como diz o ministro, não sustenta nossa práxis.

Evidentemente, o acautelamento de jovens usuários é inconstitucional e perfaz o ideal do tipo penal seletivo, excludente e segregador, preconceituoso e negador do direito de liberdade individual.

\title{
CONSIDERAÇÕES FINAIS
}

No tocante às drogas, o problema social existe, as políticas de repressão não funcionam ou, se funcionam, punem seletivamente. Como provam os dados do Infopen, jovens, negros e pessoas com baixa escolaridade estão presos em instituições que degeneram a condição humana. Conforme prescreve a Criminologia Crítica, o Brasil precisa encontrar uma forma de enfrentar o problema, isto é, investir em políticas criminais alternativas que evitem piorar a situação e agravar o fosso existente entre as classes sociais. Prender o usuário ou portador de quantidade irrisória de maconha, como se fosse traficante, apenas agrava o problema social.

Da mesma forma, a descriminalização não teria o condão de aumentar o uso entre as pessoas, como entende o senso comum, tendo em vista que há experiências exitosas em outros países demonstrando que após a descriminalização o uso da droga diminuiu. Ademais, é uma tendência mundial, até mesmo entre os países mais repressores, de flexibilizar as normas para o porte e o uso da maconha.

Vale destacar que não se pretende, aqui, desconhecer os riscos e malefícios associados ao uso das denominadas drogas, mas em realizar um exame mais aprofundado da punitividade seletiva para que a restrição penal se evidencie como necessária.

A descriminalização da maconha para uso próprio pode diminuir o tráfico de drogas 
UM DEBATE SOBRE A DESCRIMINALIZAÇÃO DA MACONHA SOB O ENFOQUE DA CRIMINOLOGIA CRÍTICA E A AUDIÊNCIA DE CUSTÓDIA COMO FERRAMENTA CONTRA A PRISÃO CAUTELAR

e a população carcerária brasileira. Em uma proposta equivalente de política criminal, as audiências de custódia se apresentam como ferramenta substancial para que o juiz de direito diferencie o verdadeiro traficante do usuário de drogas, realçando o seu papel como protagonista das garantias individuais da pessoa presa. Faça valer os direitos à individualidade e reduza os crimes contra a dignidade humana.

A audiência de custódia exerce um papel prefacial no cenário da descriminalização do uso da maconha, pois o magistrado de primeiro grau poderá verificar se a subsunção do fato típico realizada pela autoridade policial - traficante ou usuário - foi correta, impedindo o acautelamento de que não cometeram crime (senão o uso da maconha) ou pessoas envolvidas em crime de menor periculosidade.

\section{REFERÊNCIAS}

ARGÜELLO, Katie; MURARO, Mariel. Política criminal de drogas alternativa: para enfrentar a guerra às drogas no Brasil. Revista Brasileira de Ciências Criminais, $n^{\circ} \mid$ | 3 , p. 3 I5-356, abril de 2015.

ASSEMBLEIA GERAL DAS NAÇÕES UNIDAS. Pacto Internacional sobre os Direitos Civis e Políticos, de 16 de dezembro de 1966. Disponível em: http://portal.mj.gov.br/sedh/ct/legis_intern/pacto_dir_politicos.htm Acessado em 26/5/20I5.

BARRETO, Fabiana Costa Oliveira. Flagrante e prisão provisória na criminalização de furto: da presunção da inocência à antecipação da pena. Dissertação de Mestrado. Universidade de Brasília (UnB). Coordenação de Pós-Graduação em Direito, 2006.

BARROSO, Luís Roberto. RE 635.659/SP. Descriminalização do porte de drogas para consumo próprio: anotações para o voto oral do Ministro Luís Roberto Barroso. Disponível em: http://s.conjur.com.br/dl/leia-anotacoes-ministro-barroso-voto.pdf Acessado em 13/5/2016.

BRASIL. Constituição da República Federativa do Brasil de 1988. Disponível em: http://www.planalto.gov.br/ccivil_03/Constituicao/Constituicao.htm

BRASIL. Decreto n. 678, de 6 de novembro de 1992. Promulga a Convenção Americana sobre Direitos Humanos (Pacto de São José da Costa Rica), de 22 de novembro de $\quad$ e 969 . Disponível e m : http://www.planalto.gov.br/ccivil_03/decreto/D0678.htm Acessado em 26/5/20 I 5. BRASIL. Decreto 592, de 6 de jülho de 1992. Atos Internacionais. Pacto Internacional 
sobre Direitos Civis e Políticos. Promulgação. Disponível em http://www.planalto.gov.br/ccivil_03/decreto/I990-I994/D0592.htm Acessado em 26/5/20I5.

BRASIL. Lei n . I I .343, de 23 de agosto de 2006. Institui o Sistema Nacional de Políticas Públicas sobre Drogas - Sisnad; prescreve medidas para prevenção do uso indevido, atenção e reinserção social de usuários e dependentes de drogas; estabelece normas para repressão à produção não autorizada e ao tráfico ilícito de drogas; define crimes e dá outras providências. Disponível e m : http://www.planalto.gov.br/ccivil_03/_ato2004-2006/2006/lei/II 1343.htm Acessado em 17//2/2015.

BRASIL. Supremo Tribunal Federal. Voto no Recurso Extraordinário n. 635.659/SP. Alega a inconstitucionalidade do artigo 28 da Lei n'. I I.343/2006. Relator: Ministro Gilmar Mendes. Disponível e m : http://www.stf.jus.br/arquivo/cms/noticiaNoticiaStf/anexo/RE635659.pdf, Acessado em $9 / 12 / 2015$.

CANÁRIO, Pedro. STF muda entendimento e passa a permitir prisão depois de decisão de segundo grau. Disponível em: http://www.conjur.com.br/2016-fev17/supremo-passa-permitir-prisao-depois-decisao-segundo-grau Acessado em 12/5/20|6.

CARNEIRO, Henrique. História do Proibicionismo e do Movimento A n t i proibicionista. Disponível e m : https://www.youtube.com/watch? $v=Z Y r K q c l p N N Y$ Acessado em: 12/04/20 I 6.

CARVALHO. Salo de. A política criminal de drogas no Brasil: estudo criminológico e dogmático da Lei n . I I.343/06. 6ª ed. São Paulo: Saraiva, 2013.

FACCHIN, Edson. In.: Leia a íntegra do voto do ministro Fachin sobre descriminalização das drogas. Publicado em 10/09/20/5. Disponível em: http://jota.uol.com.br/leia-a-integra-do-voto-do-ministro-fachin-sobredescriminalizacao-das-drogas Acessado em 12/4/20 16.

GORGULHO, Mônica. Drogas: política de redução de danos (Parte I de 5). Entrevista realizada por Marília Gabriela. Disponível em: https://www.youtube.com/watch?v=T66cL6BnpLgAcessado em I6/4/20 16.

HABEAS CORPUS 126.292. São Paulo. Plenário 17/02/2016. Disponível em: 
UM DEBATE SOBRE A DESCRIMINALIZAÇÃO DA MACONHA SOB O ENFOQUE DA CRIMINOLOGIA CRÍTICA E A AUDIÊNCIA DE CUSTÓDIA COMO FERRAMENTA CONTRA A PRISÃO CAUTELAR

http://www.migalhas.com.br/arquivos/2016/2/art20160217-10.pdf Acessado em 12/5/2016.

INSTITUTO BRASILEIRO DE GEOGRAFIA E ESTATÍ́STICA (IBGE). Disponível em: http://www.ibge.gov.br/home/estatistica/indicadores/trabalhoerendimento/pme/pme met2.shtm Acessado em 17/5/2016.

INSTITUTO SOU DA PAZ. 67,7\% dos presos por tráfico de maconha tinham menos de 100 gramas da droga. Disponível em: http://www.soudapaz.org/o-quefazemos/materia/67-7-dos-presos-por-trafico-de-maconha-tinham-menos-de- 100 gramas-da-droga Acessado em 7//2/20 I 5.

INFOPEN. Levantamento Nacional de Informações penitenciárias. Brasília. Departamento Penitenciário Nacional: Ministério da Justiça. junho de 20 | 4. Disponível em: Disponível em: http://www.justica.gov.br/noticias/mj-divulgara-novo-relatoriodo-infopen-nesta-terca-feira/relatorio-depen-versao-web.pdf Acessado em 17/5/2016.

LEWANDOWSKI, Ricardo. In.: CANÁRIO, Pedro. STF muda entendimento e passa a permitir prisão depois de decisão de segundo grau. Disponível em: http://www.conjur.com.br/20 I 6-fev-17/supremo-passa-permitir-prisao-depoisdecisao-segundo-grau Acessado em 12/5/20 6.

MARCUSE, Herbert. A ideologia da sociedade industrial. Tradução de Giasone Rebuá. Rio de Janeiro: Zahar Editores, 1967.

MENDES, Gilmar. Voto: Recurso Extraordinário 635.659/SP. Plenário. 20/08/20I 5. D i s p o níve I e $\mathrm{m}$ : http://www.stf.jus.br/arquivo/cms/noticiaNoticiaStf/anexo/RE635659.pdf Acessado em I3/5/2016.

MOREIRA, Rômulo A. Uma vitória pírrica: o julgamento da ADPF 347. Disponível em: http://romulomoreira.jusbrasil.com.br/artigos/232387594/uma-vitoria-pirrica-ojulgamento-da-adpf-347 Acessado em 12/5/2016.

MUHEISEN, Muhammed (da Associated Press, em Haarlem, Holanda). Com criminalidade em queda, Holanda abriga refugiados em cadeias ociosas. Disponível em: http://wwwl.folha.uol.com.br/mundo/20 |6/05/I772722-com-criminalidadeem-queda-holanda-abriga-refugiados-em-cadeias-ociosas.shtml Acessado em 25/6/2016.

NETTO, José Paulo. Crise do capital e consequências societárias. Revista Serviço Social 
e Sociedade, São Paulo, n I I I, pp. 4 I3-429, jul./set. 20 I 2.

OIT/PREJAL. In: CONSTANZI, R. N. Relatório: trabalho decente e juventude no Brasil. Organização Internacional do Trabalho (OIT/Prejal). Brasília; Lima: Impresso no Peru, 2009.

PEREIRA, Alexandre B. Dilemas da Educação e do trabalho em tempos de incerteza e curto prazo: jovens, qual será o futuro? Revista Le Monde Diplomatique Brasil. ANO 9, n 99. São Paulo: Associação Palavras Livre e Instituto Pólis, outubro, 2015.

PETUCO, Denis. JC entrevista Denis Petuco: redução de danos. Disponível em: https://www.youtube.com/watch? $v=8 \mathrm{rWwRjj}$ XgEAcessado em I 6/4/20 16.

RELATÓRIO DE PESQUISA. Brasília: Instituto de pesquisa econômica aplicada, nov. $20 \mid 4$. Dis p on ível e m : http://www.ipea.gov.br/portal/images/stories/PDFs/pmas_sum\%20executivo\%20final \%20ipea_depen\%2024nov20 I4.pdf Acessado em 26/5/20I 5.

RIBEIRO, Bruno de Morais. A função da reintegração social da pena privativa de liberdade. Porto Alegre: Sérgio Antonio Fabris Editor, 2008.

ROCHA, Andréa Pires. Proibicionismo e a criminalização de adolescentes pobres por tráfico de drogas. Revista Serviço Social e Sociedade. n | | 5. São Paulo jul./set. 2013.

TERMO DE ABERTURA DE PROJETO "AUDIÊNCIA DE CUSTÓDIA". Brasília: Conselho Nacional de Justiça, 2015.

TERMO DE COOPERAÇÃO TÉCNICA n. 007/20I5, Diário da Justiça Eletrônico, Poder Judiciário, edição 68, página 4, de 16/04/20|5. Disponível em http://www.cnj.jus.br/transparencia/acordos-termos-e-convenios/acordos-decooperacao-tecnica/79069-tcot-007-20I 5 Acessado em 2/7/20I 5.

RODRIGUES, Thiago. Política de drogas e a lógica dos danos. Revista Verve, 3: 257- 277 ,
20003.
D i s p o níve I
e $\mathrm{m}$ : http://revistas.pucsp.br/index.php/verve/article/viewFile/4947/3495 Acessado em |4/4/20|6.

TOCANTINS. Tribunal de Justiça. Portaria n . 23 I/20 I 5. Diário da Justiça n 3.552. Poder Judiciário. Tocantins/TO, 6 de abril de 2015.

. Gabinete da Presidência do Tribunal de Justiça. Portaria n. 1 540/20 I 5. 
UM DEBATE SOBRE A DESCRIMINALIZAÇÃO DA MACONHA SOB O ENFOQUE DA CRIMINOLOGIA CRÍTICA E A AUDIÊNCIA DE CUSTÓDIA COMO FERRAMENTA CONTRA A PRISÃO CAUTELAR

Diário da Justiça n 3.565. Poder Judiciário. Tocantins/TO, 24 de abril de 2015.

UNIFESP. II LENAD. Levantamento de álcool e drogas: o uso da maconha no Brasil. Universidade Federal de São Paulo, 2015. Disponível em: http://www.uniad.org.br/images/stories/LENAD_Maconha.pdf Acessado em $7 / 12 / 2015$.

VASCONCELOS, Fernanda B. A prisão preventiva como mecanismo de controle e legitimação do campo jurídico. Rio de Janeiro: Lumen Juris, 2010.

THOMPSON, Augusto. A questão penitenciária. $4^{\mathrm{a}}$ ed. Rio de Janeiro: Forense, 1993.

ZACCONE, Orlando. Acionistas do nada: quem são os traficantes de drogas. $3^{a}$ ed. Rio de Janeiro: Revan, 20 II.

Recebido em: 15/05/2016 Aprovado em: 30/07/2016 